\title{
Borderline Ovarian Clear Cell Adenofibroma
}

National Cancer Institute

\section{Source}

National Cancer Institute. Borderline Ovarian Clear Cell Adenofibroma. NCI Thesaurus.

Code C40081.

An epithelial neoplasm with low malignant potential affecting the ovary. It is characterized by the presence of atypical glands and/or cystic spaces lined with clear or hobnail cells. 